\title{
MICROMORPHOLOGICAL STUDIES OF THE GENUS IPOMOEAL. (CONVOLVULACEAE) IN NEPAL
}

\author{
Saugat Shrestha $^{1}$, Nawal Shrestha ${ }^{2}$, Sangeeta Rajbhandary ${ }^{3}$ \\ ${ }^{1}$ Dhankuta Multiple Campus, Tribhuvan University, Dhankuta, Nepal \\ ${ }^{2}$ College of Urban and Environmental Sciences, Peking University, Beijing 100871, China \\ ${ }^{3}$ Central Department of Botany, Tribhuvan University, Kirtipur, Kathmandu, Nepal
}

\begin{abstract}
Ipomoea is a large and complex genus, which comprises the largest number of species within the family Convolvulaceae. Globally, the genus consists of about 600 species of vines and shrubs, which are widely distributed throughout the tropics and the subtropics. In Nepal, the genus comprises 15 species, which are distributed throughout the tropical, subtropical and temperate region of the country. Besides few enumerations and floristic surveys, no comprehensive anatomy and pollen characters of 16 species of Ipomoea occurring in Nepal to evaluate the qualitative and quantitative differences in these characters. We found that the all species of Ipomoea have paracytic type stomata. However, there is considerable variation in the size and frequency of the stomata. The size and shape of the epidermal cells also varies from species to species. Ipomoea nil has the highest stomatal frequency, while I. purpurea has the lowest frequency. All species of Ipomoea have globose, isopolar, echinate, pentoporate and radially symmetrical pollen grains. I. quamoclit has the largest pollen, while $I$. aquaticahas the smallest pollen. The anatomy of stem shows no distinct structural differences among species. Although no qualitative differences in the studied characters are found among species, there is considerable variation in the quantitative characters, such as the size of stomata, frequency of stomata and pollen size. These characters could have important taxonomic and ecological implications and therefore, are as valuable as the morphological characters.
\end{abstract}

Keywords: foliar anatomy, Ipomoea, pollen, stem anatomy, stomata.

\section{INTRODUCTION}

The family Convolvulaceae, commonly known as morning glories, comprises about 55 genera and ca. 2,000 species. The genus Ipomoea is the largest genera in the family Convolvulaceae followed by Convolvulus, Cuscuta and Jacquemontia (Judd et al., 1999). Twenty-one genera and ca. 750 species are native to the New World. The largest New World genera are Ipomoea, Jacquemontia and Evolvulus. Twelve genera have a single species (Austin, 1997). In Nepal, the family Convolvulaceae is represented by 12 genera and 45 species (Press et al., 2000). The genus Ipomoea is a large and complex genus, which comprises the largest number of species within the family Convolvulaceae. Ipomoea is usually estimated to contain ca. 600 species of vines and shrubs widely distributed throughout the tropics and the subtropics (Miller et al., 1999). It comprises annual and perennial herbaceous plants, lianas, shrubs and small trees; most of the species are twining climbing plants. In Nepal, the genus comprises 16 species, which are distributed throughout the tropical, subtropical and temperate region of the country (Press et al. 2000).

Anatomical and micromorphological characteristics of leaves, stems, and roots have 
played important roles in plant taxonomy, especially at the generic and species levels. Studies in this field have attracted the attention of plant morphologists and systematists to resolve taxonomic conflicts in different groups of plants (Saheed and Illoh, 2010; Ibrahim et al., 2015). The foliar epidermal structure has been one of the most important taxonomic characters in biosystematics and most taxonomic studies are based on the studies of the leaf epidermis. In ultra-structures such as epidermal cells, stomata, and trichomes, their sizes, lengths, distribution, orientation, and frequency are of significant importance in taxonomy as well as phylogeny (Sonibare et al., 2014). Particularly valuable taxonomic evidence has been obtained from the study of pollen, wood, leaf epidermis, trichomes and stomata (Stace, 1991). Some of these anatomical features are so diagnostic that they are now commonly used in routine identification. For example, pollen characters are useful in the identification of species of Callitriche, while trichome characters are important in identifying species in the genera Combretum and Rhododendron (Stace, 1991).

Among the many anatomical characters, stomatal character is very important in taxonomy. The arrangement of the surrounding epidermal cells or subsidiary cells in stomata is the most valuable character. Twenty seven types of stomata have been recognized by Dilcher (1974); and Stace (1991) has further added four more type of stomata in vascular plants. The occurrence of these types is often valuable at the higher taxonomic levels (Stace, 1991). The stomata type may remain the same within a genus or even in a family but the number of stomata, size and frequency of stomata often varies within a genus and even species.

Palynology is the study of spores and pollen grains. Pollen grains have a number of morphological and ultrastructural features. These palynological features have provided a wealth of characters that have been important in inferring phylogenetic relationships of plants. In addition, the features of spores and pollen grains have often been used to identify a particular plant taxon (Simpson, 2006).

In this paper, we present the outcome of extensive research on the anatomical and micromorphological characters of the 14 species of Ipomoea occurring in Nepal. Particularly, we assess the pollen morphology, stem anatomy and stomatal characters in the genus Ipomoea to evaluate its taxonomic relevance. To the best of our knowledge, this is the first micromorphological study on the Nepalese species of Ipomoea and the findings could provide important insights into the taxonomy and ecology of this genus (Retamales and Scharaschkin, 2015).

\section{MATERIALS AND METHODS}

\section{Stem anatomy}

The anatomical study of the stem and leaf were made from the fresh plant specimens collected by the first author from different regions of Nepal. For stem anatomy, fine sections were sliced from the specimens and dehydrated with alcohol series i.e. alcohol 30\% (25 minutes)alcohol 50\% (25 minutes)- alcohol 70\% (25 minutes)- safranin (25 minutes)- alcohol 70\% (15 minutes)-alcohol 90\% (25 minutes)-light green (1 minute)- alcohol 90\%-alcohol 100\% (25 minutes). The sections were finally cleared in xylene and mounted in DPX. Photographs were taken from these permanent slides and morphological characters were studied.

\section{Stomata}

For the study of stomatal characters, the lower epidermal layer of the leaf of all available fresh specimens was directly peeled off. However, 
for the dried specimens, the leaves were boiled with $10 \%$ glycerin for about 5 minutes prior to peeling. The peeled layers were stained in safranin solution and temporary slides were prepared. The stomata type and stomata frequency were studied with the help of light microscope and the measurement of stomata was made with the help of ocular and stage micrometer. The photographs of the slides were also taken for further studies.

\section{Pollen analysis}

Due to the unavailability of acetic anhydride, the pollen analysis was performed using a new method applied by Gajurel (2008). The glycerin jelly was prepared by mixing 14 gm gelatin with $150 \mathrm{ml}$ water and then left for 30 minutes. The solution was heated for an hour without boiling it until the solution was clear. About $200 \mathrm{ml}$ of glycerin was added and heated for an hour until the liquid was clear. The solution was poured on petridishes and left overnight. It was then stored in a deep freezer.

The anthers were kept in a small tube containing $10 \mathrm{ml}$ glycerin and water $(9: 1)$ for 12 hours to regain the shape of the pollens. About $4 \mathrm{ml}$ of benzyolperoxide 5 gel was taken in a tube and 4 $\mathrm{ml}$ of water was mixed. The mixture was slowly stirred. The anthers were kept in a small tube containing mixture prepared above and slightly heated until the tube was warm. The anthers were then washed and kept in a watch glass. About 2 $\mathrm{ml}$ of safranin was poured into the watch glass and the anthers were left for 2 minutes to acquire staining.

The stained anthers were crushed with a needle and mounted in a slide with glycerin jelly. Finally, the slide was observed under light microscope with magnification $15 \times 10 \mathrm{X}$ to measure the size of the pollen grains and $15 \times 45$ $\mathrm{X}$ to measure the size of the pores. Photographs were also taken as far as possible.

\section{RESULTS}

\section{Anatomy of the stem}

The stem anatomy of all the 14 available species of Ipomoea was observed in the present study (Fig. 1). The study revealed no obvious variation in the anatomy of the stem. In all the studied species, the cork is the outermost layer,which is usually superficial in origin. Just below the cork cells, the polygonal or barrel shaped single layer epidermis is present with lignified outer wall in most of the species. The epidermis is followed by polygonal or oval collenchymatous cortex, which is 7-9 layers thick in I. aquatica, I. cairica, I. mauritiana and I. quamoclit, 4-5 layers thick in I. batatas, I. triloba, I. obscura and I. turbinate, 12- 16 layers thick in I. carnea sub sp. fistulosa, and 7-10 layers thick in I. indica, I. purpurea and I. nil (Fig. 1). The secretory cells are filled with milky content when fresh, but become colourless, yellow or brown when dried. The cells are scattered in the cortical region of almost all the species.

Endodermis is single-layered, barrel-shaped parenchymatous cells, which separates the cortex and the stele. Just below the endodermis, a discontinuous ring of sclerenchymatous pericycle is present. The pericycle is singlecelled in most species but in I. batatas, I. indica, I. mauritiana, I. nil, I. obscura and I. purpurea, the pericycle is 2-3 cells in thickness. The primary phloem is very few layers in thickness followed by actively growing few cell thick cambium rings. The vascular bundles are bi-collateral, in which the xylem is enclosed by the phloem and cambium from both side. The vessels of primary xylem are small and arranged in a radial row, arranged in exarch (i.e. protoxylem lies towards the periphery and metaxylem lies towards the center). The vessels of the secondary formed xylem are very much larger and formed in certain arcs of the xylem cylinder. They are arranged in 
solitary (I. aquatica, I. carnea subsp. fistulosa, I. triloba, I. obscura, I. purpurea and I. quamoclit), or in group of 4-10 (I. batatas, I. cairica, I. hederifolia, I. indica, I. mauritiana, I. nil and I. turbinata). The inner phloem or secondarily formed phloem is filled with intraxylary phloem arranged in radial rows in the inner part of the vascular bundle. The innermost part of the stem i.e. pith, is rounded or oval shaped parenchymatous cells filled with milky, yellow or brown secretory cells, and arranged in long rows or sometimes solitary.

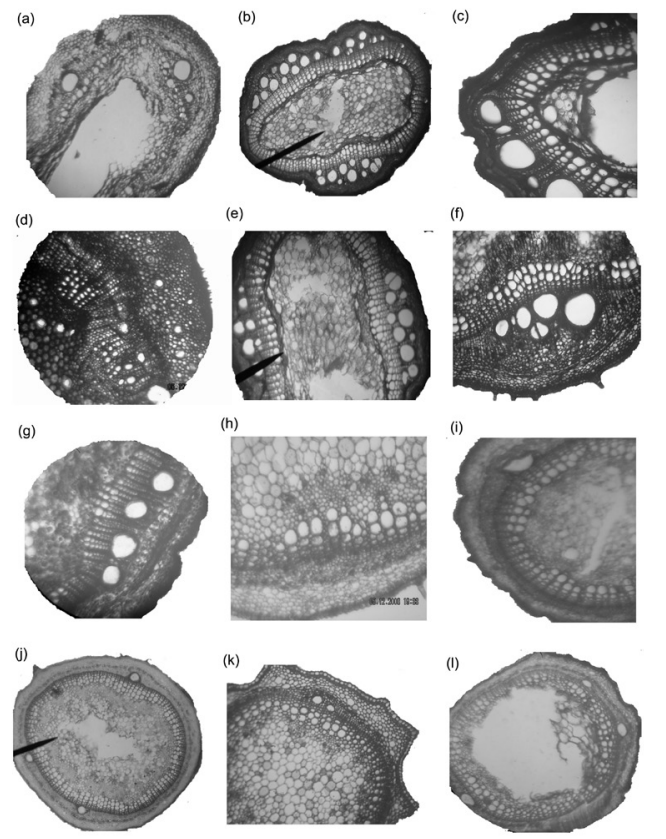

Fig. 1.Transverse section of the stem.(a) Ipomoea aquatica; (b) I.batatus; (c) I.cairica; (d) I.carnea subsp. fistulosa; (e) I. hederifolia; (f) I. indica; (g) I.mauritiana; (h) I. nil; (i) I. obscura; (j) I.purpurea; (k) I.quamoclit; (1)I. triloba.

Secondary phloem is devoid of sclerenchyma. Xylem is in the form of a cylinder and traversed only by narrow rays. The later formed vessels are larger than the primary vessels, and the size of the secondary xylem vessels varies from species to species. These are solitary or in group and more evenly distributed among the thick walled elements of the fibrous ground mass of the xylem. The pith is large, composed of parenchymatous cells with clearly visible food storage starch grains or milky, yellow or brown secretory cells.

\section{Stomatal characters}

The stomata of all species of Ipomoea are found to be rubiaceous or paracytic i.e. stomata are surrounded by two epidermal cells which is parallel to the guard cells(Fig. 2). In stomatal study, considerable variation has been observed in size and frequency of stomata. The size and shape of the epidermal cells also varies from species to species. The observed variations in the stomata of Ipomoea are presented in Table 1.
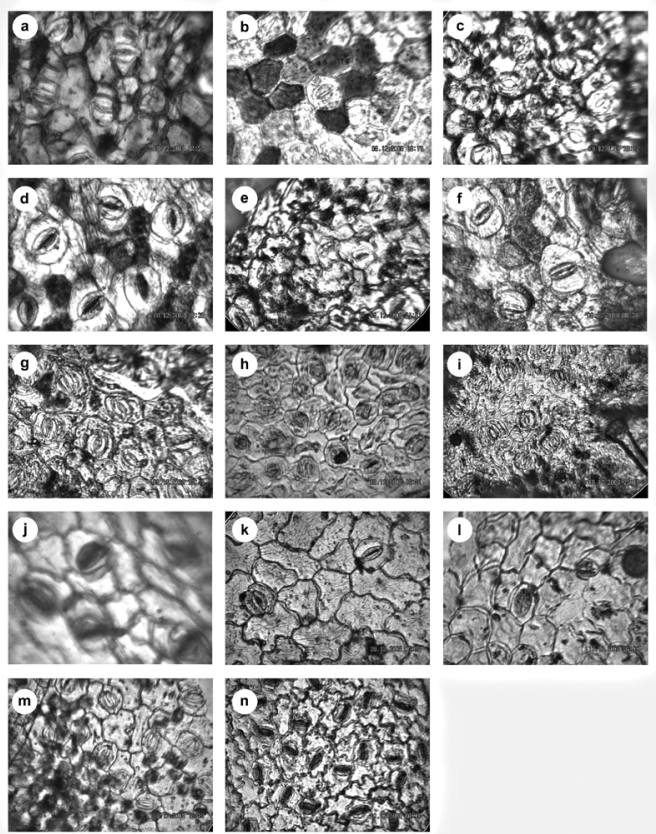

Fig. 2.Structure of stomata and epidermal cells. (a)Ipomoea aquatica; (b) I. batatus; (c) I. cairica; (d) I. carnea subsp. fistulosa; (e)I. hederifolia; (f) I. indica; (g) I. mauritiana; (h) I. nil; (i) I. obscura; (j) I. pestigridis; (k) I. purpurea; (1) I. quamoclit; (m) I. triloba; (n) I. turbinata. 
Table 1.Stomatal characters of 14 species of Ipomoea occurring in Nepal.

\begin{tabular}{|c|c|c|c|c|c|c|}
\hline \multirow[t]{2}{*}{ Name of the species } & \multirow{2}{*}{$\begin{array}{l}\text { Avg. } \\
\text { no. of } \\
\text { stomata } \\
\text { (S) }\end{array}$} & \multirow{2}{*}{$\begin{array}{l}\text { Avg. } \\
\text { no. of } \\
\text { epidermal } \\
\text { cells (E) }\end{array}$} & \multirow{2}{*}{$\begin{array}{c}\begin{array}{c}\text { Stomatal } \\
\text { Index (SI) }\end{array} \\
\begin{array}{c}\text { Sx100/ } \\
(\mathrm{E}+\mathrm{S})\end{array}\end{array}$} & \multirow{2}{*}{$\begin{array}{c}\begin{array}{c}\text { Frequency } \\
\text { per } \mathrm{mm}^{2}\end{array} \\
(\mathrm{~F}=\mathrm{S} / \mathrm{A})\end{array}$} & \multicolumn{2}{|c|}{ Stomatal size $(\mu \mathrm{m})$} \\
\hline & & & & & Guard cells & Stomata \\
\hline I. purpurea (L.) Roth. & 4 & 33 & 10.81 & 30.32 & $27.96 \times 20.38$ & $16.77 \times 4.66$ \\
\hline I. indica (Burmann, f.) Merrill. & 10 & 36 & 21.73 & 75.81 & $28.89 \times 20.50$ & $17.24 \times 3.26$ \\
\hline$I$. hederacea & 14 & 37 & 27.45 & 106.14 & $25.63 \times 5.84$ & $13.98 \times 4.66$ \\
\hline $\begin{array}{l}\text { I. carnea Jacquinsubsp. fistulosa (Mart. } \\
\text { ex Choisy)D.F. Austin }\end{array}$ & 16 & 49 & 24.61 & 121.30 & $30.29 \times 20.97$ & $12.81 \times 5.24$ \\
\hline I. hederifolia $\mathrm{L}$. & 16 & 33 & 32.65 & 121.30 & $27.96 \times 19.57$ & $19.10 \times 4.19$ \\
\hline I. quamoclit $\mathrm{L}$. & 18 & 53 & 25.35 & 136.46 & $27.49 \times 17.24$ & $16.89 \times 4.07$ \\
\hline I. aquaticaForsskal & 22 & 48 & 31.42 & 166.79 & $26.56 \times 17.24$ & $13.98 \times 6.52$ \\
\hline I. batatus (L.) Lam. & 23 & 34 & 40.35 & 174.37 & $27.96 \times 20.03$ & $14.91 \times 4.89$ \\
\hline I. cairica (L.) Sweet & 23 & 35 & 39.65 & 174.37 & $31.45 \times 23.38$ & $16.89 \times 6.99$ \\
\hline I. triloba $\mathrm{L}$. & 23 & 40 & 36.50 & 174.37 & $26.56 \times 18.64$ & $14.44 \times 4.42$ \\
\hline I. turbinata Lag. & 29 & 37 & 43.93 & 219.86 & $28.54 \times 18.05$ & $15.14 \times 4.42$ \\
\hline I. mauritianaJacq. & 30 & 37 & 44.77 & 227.44 & $28.89 \times 20.97$ & $15.51 \times 4.19$ \\
\hline I. obscura (L.) Ker Gawl. & 30 & 49 & 37.97 & 227.44 & $26.21 \times 20.38$ & $14.56 \times 5.24$ \\
\hline I.nil (L.) Roth. & 42 & 52 & 44.68 & 318.42 & $25.63 \times 16.77$ & $12.58 \times 4.42$ \\
\hline
\end{tabular}

The results show that among all the species, the stomatal frequency is highest in I. nil (318.42) followed by $I$. obscura (227.44), I. mauritiana (227.44) and I. turbinata (219.86). The lowest stomatal frequency is found in I. purpurea (30.32). Regarding the size of the guard cells, the largest size of the guard cells is recorded in I. cairica $(31.45 \mu \mathrm{m})$ and the smallest size in $I$. nil and $I$. hederacea $(25.63 \mu \mathrm{m})$. The width is highest in $I$. cairica $(23.38 \mu \mathrm{m})$ and lowest in $I$. hederacea $(15.84 \mu \mathrm{m})$. The stomatal frequency and the size of the guard cells considerably vary in different portion of the same leaf. The micromorphological study of stomata shows that there is only one type of stomata i.e. paracytic or rubiaceous type and there is no variation in the arrangement of subsidiary cells. However, the variation between the species occurs only in the quantitative characters, such as the size, number and the frequency of the stomata (Table 1).

\section{Pollen morphology}

In this study, we performed the pollen analysis of 14 species of Ipomoea. The results indicate that the shape of the pollen grains is spheroidal or globose. They are isopolar (i.e. the two polar hemispheres are the same), echinate and have a spin like outer wall with a bulbous base. The aperture of the pollen is pentoporate and the pores occur globally on the surface of the pollen grains. All the observed pollen grains are found to be radially symmetrical (Fig. 3).

Among the 14 species of Ipomoea, the largest pollen is recorded in I. quamoclit $(150.84 \mu \mathrm{m})$ and the smallest in I. aquatica $(60.92 \mu \mathrm{m})$. The spine of the pollen is largest in I. mauritiana $(11.65 \mu \mathrm{m})$ and the smallest in I. aquatica $(9.98$ $\mu \mathrm{m})$. The outer surface of the pollen is covered with numerous pores ranging from 100-200. The largest pore is found in I. carnea subsp. fistulosa $(13.11 \mu \mathrm{m})$ and the smallest pore in I. cairica 
Micromorphological studies of...

(3.48 $\mu \mathrm{m})$.

Table 2.Pollen characters of 14 species of Ipomoea occurring in Nepal.

\begin{tabular}{llllll}
\hline Name of the species & $\begin{array}{l}\text { Size of the pollen } \\
\text { with spine }(\mu \mathrm{m})\end{array}$ & $\begin{array}{l}\text { Size of the pollen } \\
\text { without spine }(\mu \mathrm{m})\end{array}$ & $\begin{array}{l}\text { Size of the } \\
\text { spine }(\mu \mathrm{m})\end{array}$ & $\begin{array}{l}\text { Diameter } \\
\text { the pore }(\mu \mathrm{m})\end{array}$ & Aperture \\
\hline I. aquatica & 60.92 & 55.94 & 4.98 & 3.65 & Pentoporate \\
I. cairica & 63.19 & 57.67 & 5.52 & 3.48 & Pentoporate \\
I. obscura & 75.31 & 64.60 & 10.71 & 5.59 & Pentoporate \\
I. triloba & 77 & 67.92 & 9.08 & 6.99 & Pentoporate \\
I. mauritiana & 81.58 & 69.93 & 11.65 & 8.43 & Pentoporate \\
I. batatus & 93.54 & 87.24 & 6.30 & 7.30 & Pentoporate \\
I. nil & 95.87 & 87.91 & 7.96 & 4.98 & Pentoporate \\
I. indica & 96.37 & 86.58 & 9.79 & 4.64 & Pentoporate \\
I. purpurea & 102.73 & 94.57 & 8.16 & 6.07 & Pentoporate \\
I. carneasubsp.fistulosa & 105.13 & 97.23 & 7.9 & 13.11 & Pentoporate \\
I. hederacea & 110.53 & 103.23 & 7.3 & 8.63 & Pentoporate \\
I. hederifolia & 110.86 & 102.56 & 8.3 & 5.97 & Pentoporate \\
I. urbinata & 113.13 & 106.56 & 6.57 & 7.96 & Pentoporate \\
I. quamoclit & 150.84 & 142.05 & 8.79 & 8.26 & Pentoporate \\
\hline
\end{tabular}

\section{DISCUSSION AND CONCLUSION}

The anatomical study of the stem and stomata shows no obvious variation among the species. It is found that the stomata of all species of Ipomoea are rubiaceous or paracytic(i.e. stomata are surrounded by two epidermal cells which is parallel to the guard cells) as described by Metcalfe and Chalk (1950).However, considerable variation occurs in the size and frequency of the stomata. The size and shape of the epidermal cells also varies from species to species and this could be an important character for delimiting species in this genus. The highest stomatal frequency is recorded in $\operatorname{I}$. $\operatorname{nil}(318.42)$ and the lowest in I. purpurea (30.32). The differences in stomatal frequencies among the species could be attributed to their habitat and growing conditions (Shields, 1950; Fahn, 1964; Fetcher et al., 1983). For example, the higher stomatal frequencies in I. nil may primarily be a response to the favourable photosynthetic conditions (Hlwatika and Bhat, 2002).

Regarding the size of the guard cells, the largest length is recorded in I. cairica $(31.45 \mu \mathrm{m})$ and the smallest in I. nil and I. hederacea $(25.63 \mu \mathrm{m})$. The width is highest in I. cairica $(23.38 \mu \mathrm{m})$ and the smallest in I. hederacea $(15.84 \mu \mathrm{m})$.

The anatomical study of the stem shows no distinct variation among the species. The outermost layer is thin walled cork cells followed by oval or barrel shaped single layer epidermis. The cortex is composed of few cells thick polygonal or oval shaped collenchymatous cells. The character is similar to that described by Metcalfe and Chalk (1950).

Palynological study reveals that in all the 14 species of Ipomoea, the pollen grains are spheroidal or globose, isopolar, pentoporate with echinate exine pattern. Although no qualitative variation in the characteristics of pollen grains is found among the species, there 
is considerable quantitative difference among them. For example, the size of the pollen grains, and size of the spine vary greatly among species and this could a useful micromorphological character for identifying species. The largest pollen size is found in I. quamoclit $(150.84 \mu \mathrm{m})$ and the smallest one in I. aquatica $(60.92 \mu \mathrm{m})$. The outer surface of the pollen is covered with numerous pores ranging from 100-200. The largest pore is found in species I. carnea subsp. fistulosa $(13.11 \mu \mathrm{m})$, while the smallest one occurs in I. cairica $(3.48 \mu \mathrm{m})$.

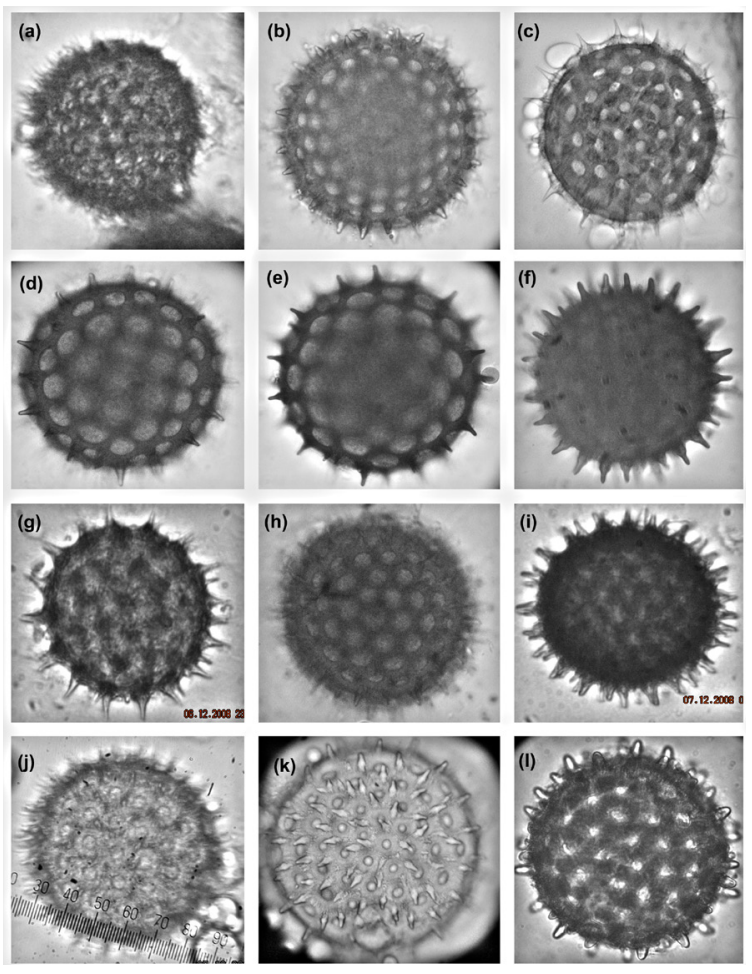

Fig. 3.Pollen grains of Ipomoea. (a)Ipomoea aquatica; (b) I. batatus; (c) I. cairica; (d) I.carnea subsp. fistulosa; (e)I.hederifolia;(f) I. indica(g) I.mauritiana;(h) I. nil; (i) I. obscura; (j)I. purpurea; (k)I. quamoclit; (1)I. turbinata. Pollen size has often been shown to be associated with performance traits such as pollen tube length and growth rate. McCallum and Chang (2016) report the exceptionally clear results of a greenhouse study designed to detect the functional significance of genetically based variation in pollen size in Ipomoea purpurea. Following an artificial selection experiment that succeeded in creating divergent lines with respect to pollen grain size, they conducted mixed pollinations containing both large and small pollen grains followed by the analysis of microsatellite markers among the resulting seeds to determine paternity. They found that the size of individual pollen grains had a strong and positive effect on siring success, although the success of large- relative to small-grained pollen donors differed among pollen recipients. Overall, our study shows that the micromorphological characters studied herein may have important taxonomic and ecological implication. Although no qualitative differences in the studied characters are found among species, there is considerable variation in the quantitative characters, such as the size of stomata, frequency of stomata, pollen size, etc. These characters could have strong taxonomic significance and therefore, should not be neglected.

\section{ACKNOWLEDGEMENTS}

We would like to thank Prof. Krishna K. Shrestha, Prof. Ram P. Chaudhary, and Dr. Suresh Ghimire for their guidance and support during this work, Prof. Mohan Siwakoti for his help in species identification. We would also like to thank the Chief of the national herbarium (KATH) for offering us the opportunity to examine the specimens.

\section{REFERENCES}

Austin, D.F. (1977). Ipomoea carneaJacq.Vs. Ipomoea fistulosa Mart. Ex Choisy.Taxon 26: 235-238.

Case, A., P. Curtis and A. Snow (1998). Heritable variation in stomatal responses to elevated $\mathrm{CO}_{2}$ in wild radish, Raphanusraphanistrum 
(Brassicaceae). American Journal of Botany 85(2): 253-258.

Dilcher D.L. (1974). Approaches to the identification of angiosperm leaf remains. Botanical Review 40: 1-157.

Fahn, A. (1964) .Some anatomical adaptations of desert plants. Phytomorphology 14: 93102.

Fetcher, N., B.R. Strain and S.F. Oberbauer. (1983). Effects of light regime on the growth, leaf morphology, and water relations of seedlings of two species of tropical trees. Oecologia 58: 314-319.

Gajurel, J.P. (2008). Taxonomy of the Family Commelinaceae in Nepal.Master's Thesis. Central Department of Botany, Tribhuvan University, Kathmandu.

Hlwatika, C.N.M. and R.B. Bhat (2002). An ecological interpretation of the difference in leaf anatomy and its plasticity in contrasting tree species in Orange Kloof, Table Mountain, South Africa. Annals of Botany 89(1): 109-114.

Ibrahim, J.A., O.F. Kunle and A.E. Ayodele (2015). Anatomical features of the transverse sections of the leaves of Loranthaceae in Nigeria. International Journal of Pharmacognosy and Phytochemical Research 7 (3): 489-501.

Judd, W.S., C.S. Campbell, E.A. Kellogg and P.F. Stevens (1999). Plant Systematics; A Phylogenetic Approach. Sinauer Associates Sunderland, Massachusetts, USA.

Matcalf, C.R. and L. Chalk (1950). Anatomy of the Dicotyledons 2 vols. Clarendon Press, Oxford, UK.

McCallum, B. and S.M. Chang (2016). Pollen competition in style: Effects of pollen size on siring success in the hermaphroditic common morning glory, Ipomoea purpurea. American Journal of Botany 103: 460 - 470.
Miller, R.E., M.D. Rausher and P.S. Manos (1999). Phylogenetic Systematics of Ipomoea (Convolvulaceae) Based on ITS and Waxy Sequence. Systematic Botany $\mathbf{2 4}$ (2): 209-227.

Press, J.R., K.K. Shrestha and D.A. Sutton (2000). Annotated Checklist of the Flowering Plant of Nepal. The Natural History Museum, London.

Retamales, H.A. and T. Scharaschkin (2015). Comparative leaf anatomy and micromorphology of the Chilean Myrtaceae: Taxonomic and ecological implications. Flora - Morphology, Distribution, Functional Ecology of Plants 217:138-154. Saheed, S. A. and H. C. Illoh (2010). A Taxonomic Study of some Species in Cassiinae (Leguminosae) using Leaf Epidermal Characters. Notulae Botanicae Horti Agrobotanici Cluj-Napoca 38(1): 21-27.

Shields, L.M. (1950). Leaf xeromorphy as related to physiological and structural influences. Botanical Reviews 16: 399-447.

Simpson, M.G. (2006). Plant Systematics. Elsevier Academic Press, Burlington, USA, San Diego, California, USA and Theobald's Road, London, UK

Sonibare, M.A., T.A. Oke and M.O. Soladoye (2014). A pharmacobotanical study of two medicinal species of Fabaceae. Asian Pacific Journal of Tropical Biomedicine 4(2): 131-136.

Stace, C.A. (1991). Plant Taxonomy and Biosystematics ed. 2. Cambridge University Press, Cambridge.

(Received 16 Aug 2017, revised accepted 19 Sep 2017) 